\title{
An undisclosed story of roses: church, state, and nation in contemporary Georgia
}

\section{Tornike Metreveli}

To cite this article: Tornike Metreveli (2016): An undisclosed story of roses: church, state, and nation in contemporary Georgia, Nationalities Papers, DOI: 10.1080/00905992.2016.1200021

To link to this article: http://dx.doi.org/10.1080/00905992.2016.1200021

Published online: 10 Aug 2016.

Submit your article to this journal $\square$

Џ Article views: 9

Q View related articles $\sqsubset$

View Crossmark data $\longleftarrow$ 


\title{
An undisclosed story of roses: church, state, and nation in contemporary Georgia
}

\author{
Tornike Metreveli* \\ Department of Social Sciences, University of Bern, Bern, Switzerland
}

(Received 4 June 2015; accepted 10 December 2015)

\begin{abstract}
Since the Rose Revolution (2003), Georgia has encountered an unprecedented scale of institutional reforms concomitant with the rise of American and European involvement in the "democratization" process. Various scholars have suggested that Georgian nationalism developed from an ethno-cultural basis to a more civic/liberal orientation after the Rose Revolution. This paper analyzes Georgian nationalism under President Mikheil Saakashvili to demonstrate the significant divergence between political rhetoric on national identity, the selection of symbols, and state policy toward the Georgian Orthodox Church versus state policy toward ethnic minorities. The aim of this article is to examine the at times conflicting conceptions of national identity as reflected in the public policies of Saakashvili's government since the Rose Revolution. It attempts to problematize the typologies of nationalism when applied to the Georgian context and suggests conceptualizing the state-driven nationalism of the post-Rose Revolution government as "hybrid nationalism" as opposed to civic or ethno-cultural.
\end{abstract}

Keywords: Georgia; nationalism; Orthodox Church; Rose Revolution; national identity

\section{Nationalism: concept, discourse, and typology}

The fall of Soviet Communism was accompanied by a multifaceted power struggle for reshaping the new order in successive nation-states. Georgia was not an exception. Over the last 25 years, the country went through gaining independence from the Soviet Union (1991); civil war in the capital of Tbilisi (1993); two internal wars in South Ossetia (1991-1992) and Abkhazia (1992-1993); the Rose Revolution (2003); and the war with Russia (2008). Over this time frame, Georgian nationalism arguably evolved from being predominantly ethno-cultural under the presidency of Zviad Gamsakhurdia toward being more civic/liberal and secular in character under the presidency of Mikheil Saakashvili (Jones 2006; Nodia 2009; Zedania 2009). In the following sections, I will try to illustrate that ethno-cultural elements of national identity as reflected in the policies of the state coexisted with civic and secular concepts of nationhood. This discrepancy between on the one hand political speeches of the ruling elites, the selection of national symbols, and symbolic acts, and on the other hand an implementation of religious and ethnic policies constitutes an interesting case for the theoretical approach to the study of nationalism.

As a starting point, I will begin with Will Kymlicka's working definition of the "nation." He defines the nation as "a historical community, more or less institutionally

*Email: tornike.metreveli@ soz.unibe.ch 
complete, occupying a given territory, or homeland, sharing a distinct language and culture" (Kymlicka 1995, 11). When referring to a nation as a "historical community," it is not seen as an ancient pre-given entity; rather I adopt a modernist approach, seeing it as a more modern phenomenon (Gellner 1983). "Nationalism" is a political principle or an ideological movement that may politicize and instrumentalize ethnicity and culture by using different discursive constructs or social communications (Anderson 1991; Deutsch 1966, 29). Nationalism, we are told in Ernest Geller's seminal account, is a historical process based on "a political principle, which holds that the political and the national unit should be congruent" (Gellner 1983, 1). As a historical process, nationalism "invent[s] nations" where there are none (Gellner 1964, 168). It is irrelevant whether the nation has ethnic ties with the past or distinctive cultural roots, because nationalism can invent those roots without any preconditions or connection to antiquity (Gellner 1983, 85).

Another classic account of nationalism by Anthony Smith defines it "as an ideological movement to attain and maintain autonomy, unity and identity on behalf of a population, some of whose members believe it to constitute an actual or potential 'nation"' (Smith 2009, 61). To succeed, nationalism needs a connection to the past through memories, myths, symbols, and shared values. This pre-modern cultural and social foundation unites people with the past, which in turn establishes connectivity with the present (Smith 1991). As a political ideology, nationalism integrates pre-modern constructs (historical narratives, myths, and memories) to further generate political claims for various groups. These groups do not necessarily have to have shared cultural traditions and histories. Decisive for nationalism is the construction of those narratives for the purpose of political mobilization.

Various scholars outlined the distinction between the two (ideal) types of nationalism. So-called ethnic nationalism developed in nations which were late to modernize (Kohn 1944, 329-331), and/or were colonized, or which continuously experienced a struggle for an independent state but rarely achieved it. Under these circumstances, culture was perceived as threatened by outsiders and nationalism lacked a sense of political loyalty toward the state (Smith 2009, 67). This nationalism contained more ethnic, organic, and racial sentiments in terms of defining "us" and "others;" consequently, it was exclusive toward "others" even in cases of achieving/regaining statehood. In contrast, the civic type is considered to be the opposite of ethno-cultural nationalism. It is culturally thinner (more flexible) and allows "others" (e.g. immigrants and minorities) to belong to the nation, but under varying conditions. These conditions could demand an adherence to the values of the society they resided in. The key principle for being part of the nation, however, was citizenship, with certain conditions for newcomers to acquire citizenship (Brubaker 1992; Greenfeld 1992, 10-12; Smith 2009).

The civic/ethnic conceptualization was rightly criticized for being too vague, ideal-type, broad, and Eurocentric. The perception of external threats can make both civic and ethnic nationalisms exclusive and illiberal. The position of political elites in the process of articulating nationalism is decisive for shaping its nature (Brown 2000). Whether one conceptualized it as civic or ethnic, most people are born into their nationality (Yack 1999). Consequently, civic identity is a similarly inherited cultural construct to that of ethnic identity. National communities per se are the carriers of "inherited cultural baggage." For some, this "baggage" contains the myths of past glories and is based on an organic commonality; for others, it carries political traditions and certain cultural norms which are transmitted from generation to generation. Still, drawing a precise line between the "rational attachment to principle and the emotional celebration of inherited culture" is almost impossible, and is considerably more complex than the ethnic/civic binary implies (Yack 1999, 105-109). 
Whether nationalism is a discourse, an ideology, a political movement, or the combination of the three, nationalism could have both ethnic and civic elements. In the case of the former, belonging to the nation is exclusive and determined by jus sanguinis (Brubaker $1992,1)$ and discourse is dominated by cultural particularism, whereas the latter limits belonging to citizenship and tends to be culturally thinner and relatively inclusive to newcomers. Elites play a central role in articulating nationalism as a discourse, or employing it as an ideology. The rest of this paper examines conflicting conceptions of national identity as reflected in the religious policy of the state under Saakashvili's government, and contrasts this with civic elements as articulated in the discourse of the president and state's policy toward ethnic minorities. The paper offers several explanations to this dichotomy and conceptualizes a typology of nationalism derived from the Georgian case.

\section{Time frame and research methodology}

The period after the Rose Revolution (Saakashvili's two-term presidency 2004-2012) constitutes a special case for Georgian nationalism. This time frame saw an unparalleled rise of Western involvement in Georgia, a series of institutional reforms unseen in the history of the country, and a strongly pro-Western government with ambitions to reform Georgian society. Georgia was on the Western radar during Eduard Shevardnadze's presidency too, when the state received direct American aid in the range of $\$ 778$ million in the period between 1992 and 2000 (Jakopovich 2007; Lazarus 2010; Tudoroiu 2007). However, the most notable rise in Western aid for "democracy promotion projects" in Georgia starts with the Rose Revolution and sees a drastic increase after the Russo-Georgian War (2008). In addition, precisely after the Rose Revolution, the Saakashvili government established the practice of allocating unprecedented funding and land properties to the Georgian Orthodox Church (GOC) and its leaders, making the church arguably the strongest social institution in the country (Nodia 2009). In parallel with religious policy, the state contrasted that with a relatively inclusive ethnicity policy and strong emphasis on the multicultural nature of Georgian nationhood in the president's political speeches. Keeping in mind the above-discussed frame of civic versus ethnic nationalism, it is useful to explore how these key ideas are reflected in an appropriate case study, and also to what degree this reflection can help us understand the case itself.

Inspired by the work of Gale (2001), I use "critical policy analysis" (Henry 1993; Marshall 1997; Prunty 1985; Taylor 1997) to analyze the religious and ethnicity policy of President Saakashvili's government. In line with Jenny Ozga who theorized policy sociology as "rooted in the social science tradition, historically informed and drawing on qualitative and illuminative techniques" (Ozga 1987, 144), this method helps to see important relationships between the specific angle of policy and discursive constructs simultaneously (Apple 1996). The paper takes an institutional approach and triangulates religious and ethnicity policy analysis with data from media outlets/NGO reports, legal analysis, political speeches, and public opinion surveys.

\section{Westernizing Georgia: on paper and in practice}

The Soviet collapse did not bring Georgia into the spotlight of Western aid and geopolitical interests. The country was "little more than a failed state" (Tudoroiu 2007, 319) with two regions (Abkhazia and South Ossetia) de facto lost, a civil war in the capital of Tbilisi, tense interethnic relationships between the Armenian minority population and the Georgians in Javakheti, and the nationalism of former President Gamsakhurdia. It is important to 
reflect on the scale of American and European assistance to Georgia in order to further understand the context of adoption of laws and analyze the broader implications of the government's pro-Western politics on reinforcement of religious nationalism.

One can argue that Georgia gained (geo)strategic importance for the West (for Russia, Georgia never lost its geo-strategic importance) after the launch of the Baku-Tbilisi-Ceyhan pipeline in 1994 that potentially created an alternative route for Caspian Sea oil to be transmitted through Georgia to Turkey and then on to Europe. This was seen by a number of analysts as the key American security interest in the region in order to diversify the dependency of the USA on Middle Eastern oil-rich states (Jakopovich 2007; King 2004, 15; Tudoroiu 2007, 320). Another energy security project, the Baku-Erzurum gas pipeline, also created with the assistance of Americans, went through Georgia and created an alternative to Russian state-led Gazprom projects and carried a message to Russia that the USA was interested in the region historically dominated by a hegemonic Russian foreign policy. In addition to political support and economic assistance, soon after the 11 September 2001 attacks, the USA started to provide military assistance to Georgia. In 2002 Washington participated in counterterrorism operations and technically equipped Georgian troops (Giragosian 2004, 57). This was accompanied by various NGO development projects where George Soros' Open Society Institute (OSI) was a key actor in financing the Georgian nongovernmental sector. OSI training in nonviolent protest techniques was important against unpopular President Eduard Shevardnadze (Fairbanks 2004, 115; Mitchell 2004, 346). Additionally, various democracy-building and effective governance projects, election system reform, local governance, and judicial reform were jointly funded by the EU and US Agency for International Development (USAID) (Tudoroiu 2007).

If between 1992 and 2003 Georgia received approximately \$1 billion from the US government, after the Rose Revolution the share of so-called capacity-building, efficient governance, and democracy project funding almost trebled (Tudoroiu 2007). Additionally, the government received a joint sum of $\$ 4.5$ billion in aid from the USA, EU, World Bank, the Asian Development Bank, and others for post-2008 August war rehabilitation projects (Jones 2006, 41-42). The combined amount of aid funds put Georgia second after Israel in terms of being a beneficiary of American aid programs (Jakopovich 2007). A couple of months after the end of the Russo-Georgian war in August 2008, 38 countries and 15 international organizations donated a total of $\$ 4.5$ billion in aid to Georgia. Of that, the USA provided \$1 billion (Lazarus 2010), including \$50 million for "security assistance" programs (Congress Research Service 2008, 34). The European Union offered $€ 500$ million, while the International Monetary Fund allocated $\$ 750$ million (Civil Georgia 2008). President George W. Bush's government put Georgia into its new Millennium Challenge Fund with $\$ 300$ million in development aid (Congress Report Service 2008, 31).

In parallel with financial assistance, the involvement of foreign aid agencies (e.g. the USAID) in funding and training of the staff of the president and prime minister in "communication and outreach" and assistance in judiciary and structural reform programs four years after the Rose Revolution was seen in the wider public as a source of legitimization for the Saakashvili government. The government in turn used various reports and economic freedom rankings as a point of reference for measuring the success of reforms in the eyes of the international community (Lazarus 2010). This symphony between Western governments and Saakashvili's government strengthened the position of anti-Western clerics within the church (Ladaria 2012, 111; Serrano 2014). Western institutions were perceived as Saakashvili's political backup, and as some argued, there emerged a certain conflict between the (self-defined) liberal, modernizing, and secularizing government of Saakashvili, and what some saw as the conservative, anti-modern, and backward-looking nationalist 
church (Filetti 2013; Gavashelshvil 2012; Kekelia 2012; Ladaria 2012; Ratiani 2011; Serrano 2010, 2014; Tevzadze 2009, 2010; Zedania 2009).

The considerable political and financial support given to the Georgian state under Saakashvili from the USA and the EU came with conditions. However, the expectations of foreign and domestic actors did not necessarily coincide. Complex geopolitical interests and high political stakes were involved in creating "project Georgia" as a "beacon of democracy" (Companjen 2010, 25) in the region and to a certain degree obliged the Georgian government to harmonize both its legal framework and its policy and implementation with the requirements of the EU and various foreign donors. The challenge of accommodating diverging domestic and foreign interests is reflected in dichotomies between political speeches and religious and ethnicity policy. On the one hand, the government faced rather isolated ethnic minority communities in the Javakheti and Kvemo Kartli regions which considerably lagged behind mainland Georgia in almost all socioeconomic and cultural aspects of life, and on the other hand, an increasingly popular GOC with its own political and economic agenda and growing assertions to influence the balance of power for its own benefit. One needs to bear in mind this complex political context while studying the adoption of laws and policy implementation and discrepancies between different conceptions of nationhood. The modernizing agenda of the government was accompanied by inconsistency between its religious policy, selection of symbols, and discourse, which actually favored the GOC, strengthening its political and economic capital.

\section{An image of a secular liberal}

Mikheil Saakashvili, a former member of Eduard Shevardnadze's government and US-educated lawyer, was brought to power in 2004 in the wake of the November 2003 Rose Revolution. After winning the presidential election with $96.24 \%$ of the vote (Wheatley 2005, 191-194), Saakashvili declared the integration of all national minorities into the "newly born" Georgian nation as his top priority.

In his inaugural address, Saakashvili affirmed his belief in a multicultural Georgia and stated that:

Georgia is home not only for all Georgians, but also for all ethnic minorities, residing in Georgia. Every citizen, who considers Georgia as his homeland, be he Russian, Abkhazian,

Ossetian, Azerbaijani, Armenian, Jewish, Greek, Ukrainian, Kurd - is our greatest wealth and treasure. (Saakashvili 2004)

This speech illustrated his civic nationalist vision of the future of the Georgian state and the importance of creating what Will Kymlicka calls a common "societal culture." Civic discourse is present in many of Saakashvili's speeches both during the early phase of his first term as president and later on. On another occasion, he responded to the ethnonationalists:

If somebody hates Armenians, I Mikheil Saakashvili will be an Armenian with him, if somebody hates Ossetians I will be an Ossetian with him. [If they] hate Azeris? - I will be an Azeri, [if they] hate Jews? - I'll be a Jew but still I will remain the greatest Georgian because patriotism is not measured by people's origin - but by the efforts of people like you. (Saakashvili 2005)

Unlike his predecessors, Saakashvili from time to time emphasized the importance of equality between all ethnic groups in the model of the Georgian state which he intended to build, and openly offered reunification initiatives to the Abkhazian and Ossetian minorities (Saakashvili 2008a, 2008b, 2008c). If one only analyzes his inaugural speeches, Saakashvili's discourse is civic; however, there were some contradictions between the officially 
promulgated state-driven civic discourse and policy on the one hand, and his symbolic actions on the other.

For instance, on the day of his inauguration, Saakashvili signed a decree according to which the medieval Georgian five-cross flag (similar to St. George's cross, with four additional Orthodox Christian crosses on each quarter of the rectangle) was (re)established as the national flag (Jones 2013, 226). Designed after the Jerusalem cross, the flag emphasized Georgia's historical belonging to a Christian civilization, according to Saakashvili (Saakashvili 2008c). This was part of the reason why its adoption was strongly supported by the GOC. Bearing in mind that almost $10 \%$ of the Georgian population is Muslim, while around 7\% belongs to other religions (Broers 2008), restoring a flag that underlined Georgians' Christian roots was perhaps not hugely inclusive for the religious and ethnic minorities whom Saakashvili sought to accommodate in the "newly born" Georgian nation (Jones 2013, 226-227).

This symbolic gesture was not met with serious protests from national minorities or from the majority of Georgians. The minorities did not protest partly because the two regions (Javakheti and Kvemo Kartli) where they mostly reside were almost completely isolated from the sociopolitical discourse of the center after Shevardnadze, whereas the majority of Georgians, still quite ethno-nationalist at the time, strongly favored the adoption of the new flag. For instance, a popular opinion was that since this flag was used in the fourteenth century, during the Golden Age of the Georgian Kingdom, its restoration would be a symbolic reaffirmation of the glorious past and optimistic future (Eurasianet 2004). The majority of Georgians did not question to what degree the new flag was inclusive for minorities on the symbolic level. Saakashvili used civic ambivalence toward this issue to gain extra patriotic points from the nationalist part of the Georgian population. Another possible reason for adopting the new flag could be a purely political calculation: to link the new state symbols with those of the ruling party. The United National Movement (UNM), Saakashvili's party, used the five-cross flag during the Rose Revolution. In a sense, as some have suggested, this flag became the symbol of resistance to the corrupt regime (Jones 2013, 22). One might suggest that Saakashvili, at least on the symbolic level, was favoring the majority Georgian (Christian) culture at the expense of neglecting minorities (the potential dissatisfaction of almost one-fifth of the Georgian population). The flag with Christian crosses, as a symbol, partly reaffirmed that Georgia historically belonged to a Christian civilization. However, precisely the reaffirmation of the latter on a symbolic level illustrated that Saakashvili's nationalism had elements of ethno-cultural particularism. This does not necessarily mean a rejection of civic ideas or an exclusive embrace of Christian Orthodoxy, but, whether for political calculations or symbolic reasons, an act of reinventing the national flag could have carried a powerful symbolic message to the non-Christian population that the Georgian state, to which they historically belonged to, was Christian in the first place. However, in 2010-2011 Saakashvili started attending the services of minority churches (Jews, Baptists, Catholics, Armenians, and Muslims). Previously, presidents only visited ceremonies of the GOC.

Another illustration of contradictions was his pilgrimage to the grave of King David the Builder (the ruler of the united Georgian Kingdom of the Golden Age in the eleventh century) and the oath taken there. Prior to his inauguration, Saakashvili had been blessed by the patriarch of Georgia to "unify the country," and at King David's tomb he took an oath to restore its territorial integrity and return Abkhazia and Ossetia to Georgian control (Wheatley 2009). Bearing in mind Georgia's ethno-nationalist past of the early 1990 s, the symbolic manifestation of his nationalism was illustrated in his pilgrimage to the tomb and the oath, the blessing from the patriarch to unite Georgia, the reestablishment 
of the historically glorious national flag, and unification and might have sent hesitant signals to minorities in Abkhazia and Ossetia. One might argue that the visit to King David's grave had multiple meanings in terms of how national identity could be reflected in a symbolic act. On the one hand, due to the sensitivity of symbols and nationalist rhetoric in Georgian history, at first glance this might portray Saakashvili as an ethno-nationalist in the eyes of Ossetian and Abkhazian minorities. On the other hand, by choosing King David as his model, Saakashvili could have sought to illustrate that like the medieval Georgian king, who was known (or is mythologized) for his tolerance, he also by means of force and diplomacy endeavored to achieve interethnic peace and a harmonic coexistence. If one examines the pilgrimage from a different perspective, paying less attention to the role of King David the Builder in Georgian history and looks at it from the perspective of political appeal, Saakashvili's visit to the king's grave could be interpreted as an act of winning the hearts and minds of the nationalist electorate based in Western Georgia (mostly first President Zviad Gamsakhurdia's supporters), and/or an attempt to balance growingly unpopular secularizing reforms (which are discussed below).

\section{The making of Frankenstein: the legal aspect}

Elements of ethno-cultural particularism in Saakashvili's nationalism were not just illustrated by the selection of symbols, but mainly in policies toward the church, particularly in terms of funding and property restitution. However, to understand the special relationship of the state and church, one needs a broader historical and cultural context. The GOC has been the most trusted public institution in the country for more than a decade. Various data indicate the staggering popularity of Patriarch Ilia II (Ilia Shiolashvili), making him the highest-ranking public profile person with an approval (like/dislike) rating varying from $91 \%$ to $96 \%$ (see National Democratic Institute polls June 2012-August 2014). The high popularity of the church and its leader must be interpreted in a specific historical and cultural context. Miklós Tomka suggests considering different aspects of religious communities, religious culture, and institutional and organizational apparatuses of religion in order to understand the religious state of affairs in former Communist Eastern Europe. Orthodox Christian religious practice emphasizes the importance of worship, icons, religious symbolism, and tradition, in addition to religious faith (Tomka 2011, 15-20). A noteworthy distinction between Eastern Orthodox traditions and some other Christian denominations is that religious worship and rituals do not necessarily manifest individual beliefs; neither religious practice nor participation in the rituals automatically echoes the depth of personal conviction or religious belief. At times, if not quite often, national identity is intertwined with religious identity. For example, when people identify themselves with a religious denomination, this does not necessarily mean their identification with the church but with national culture and/or tradition (Payne 2007; Ramet 2006).

Since the early stages of the Communist dictatorship (1923-1943), the GOC was brutally repressed by state-led atheism. Bolshevik policy aimed at the complete eradication of religion: thousands of priests were persecuted and killed, churches were closed or reconstructed into public houses, but nevertheless a complete eradication of the church proved to be impossible as religion was identified more with culture and tradition rather than purely theology, liturgy, and dogma. From World War II until Joseph Stalin's death, church leaders were offered state funds and some infrastructure: seminaries were opened and religious publications were allowed. This was Stalin's policy for establishing control over the private space of the religious part of society. Religion was used for the justification 
of ideology (however dichotomous it may sound within atheist ideology) and the strengthening of public morale during World War II (Ratiani 2011).

Soon after the collapse of the Soviet Union, economic liberalization and globalization were accompanied by the GOC's push to fill the sociocultural and ideological vacuum left after the collapse of old structures and Communist ideology (Sulkhanishvili 2012). Georgia was facing civil wars and internal military conflicts in South Ossetia (1991-1992) and Abkhazia (1992-1993). Given the circumstances, in line with deprivation theory (Furseth and Repstad 2006; Glock, Ringer, and Babbie 1967; Glock and Stark 1965; Rice 2003; Roof 1976; Stark and Bainbridge 1980; Zuckerman 2008), the more people felt materially deprived as an outcome of wars, poverty, and civil unrest, the more they searched for spiritual well-being and leaned toward repressed traditions. The church filled the power vacuum left over from Communism and the weakness of state institutions and managed to consolidate considerable political capital (Nodia 2009; Serrano 2010).

The rise of public support for the church was translated into a constitutional agreement between the church and state (in Georgian known as the Concordat) signed by President Eduard Shevardnadze in 2002. This document gave unprecedented authority to the GOC to be exempt from taxes, freed religious clerics from military service, and gave the patriarch of Georgia a special legal status. In addition, Orthodox priests were exclusively given the right to enter the penitentiary system, particularly prisons, and maintain an Orthodox Christian corner inside of prisons. The constitutional agreement also guaranteed the church the right to appoint teaching personnel responsible for religious studies in public schools and the adoption of the program (Chikvaidze 2005, Article 5 of the Constitutional Agreement). Article 11 declared,

the State confirms that material and moral damage was inflicted on the Church during the period of deprivation of statehood in the 19th and 20th centuries (especially in the period 1921-1990). As the actual possessor of the confiscated wealth, the [State] takes responsibility for compensating part of the material damage.

The GOC was the only Christian organization in the country that received state funding. In line with the church-state constitutional agreement, the GOC is being compensated for the damage caused during the Russian Empire (1801-1917) and USSR (1921-1990). While the Georgian state is not the legal inheritor of the Soviet Union, it still took the responsibility to compensate the GOC for both economic and moral damage (Grdzelidze 2009). The fourth paragraph of Article 6 of the church-state agreement defined financial mechanisms for the GOC including "voluntary contributions, corporate income, investments, grants, donations, and other income received in accordance with applicable law" (Article 6, Paragraph 4).

The monopolist position of the GOC on the religious market of the country was to some degree challenged by the Law on General Education (2005) initiated a year after Saakashvili's presidential inauguration. The law had a laïcist inertia where the state (1) guaranteed independence of public schools from religious unions (Article 3); (2) established principles of neutrality and nondiscrimination and prohibited the use of public schools for religious indoctrination, proselytism, or forced assimilation (Article 13); (3) assured that religious symbolism would be used in high schools only for academic purposes and not for the purpose of propaganda or indoctrination (Article 18); and (4) moved the study of religion in high schools from the compulsory to a nonacademic noncompulsory subject (Article 13.2 of the Georgian Law on General Education). With the amendments to this law, the state attempted to eliminate an ingrained connection between the education system and a religious institution. The secularist assertions of the government were "grafted from abroad" onto Georgian society (Jones 2013, 110). The hectic pace and extent of radicalism of 
legal and institutional reforms, ${ }^{2}$ the growing dissatisfaction of the public with their outcomes, and the complexity of domestic and foreign interests resulted in a complicated political context for the further implementation of reforms. On the one hand, the Saakashvili government faced domestic confrontations with an opposition led and funded by billionaire Badri Patarkatsishvili and his media channel Imedi; on the other hand, a public growing dissatisfied with the outcome of reforms and the church was stirring ethnic nationalism and hindering reforms (Tevzadze 2009). The government faced a dilemma of how to balance between conflicting geopolitical situations: a strongly pro-Western foreign policy and unprecedented foreign aid versus an increasingly assertive Russian policy and its regional interests. The power struggle would have an important impact over the conception of national identity as reflected in the implementation of policies and the adoption of laws.

The implementation of the Law on Education is a good example of the aforementioned controversy. The law moved religion from the public space only on paper. In practice, teachers of Georgian literature, for example, who under the new curricula were forced to teach hagiography (a biography of saints, previously taught under religious studies) emerged as preachers of the Orthodox Christian religion. Collective prayer became a part of the learning process. Later research on a sample of public schools in Tbilisi confirmed that the Old Testament was taught in the third and fourth grades, while the New Testament was taught in the fifth and sixth grades (Gvinianidze and Barkaia 2014). The textbooks used for teaching were neither approved nor coordinated with the Ministry of Education. There existed no effective institutional mechanisms for overseeing this process. The removal of religion from public schools resulted in a series of massive protests against the government (Jones 2013).

In order to balance an increasingly dissatisfied church, which on various occasions expressed dissatisfaction with certain reforms, in 2006, Saakashvili's government amended the tax code. Unlike in many liberal states where the state exempts religious organizations from paying various taxes, the Georgian government was selective with the GOC, granting it an exclusive tax-exempt status not available to other religious groups (International Religious Freedom Report 2005). As a result, the GOC became free of revenue tax and its products (imported church utensils and products such as incense), noncommercial property, and land could not be taxed (Grdzelidze 2009). In addition, the Saakashivili government adopted a new clause in the tax code (Sak 'art'velos sagadasakhado kodeqsi 2010) that defined religious activities as noneconomic activity (Art. 9) and religious organizations became free from property taxes (noncommercial property and land) (Art. 206, 30), while the patriarchate was exempt from revenue taxes (Art. 99, 168). Moreover, the same law in Article 219 exempts the head of the Orthodox Church (Patriarch of Georgia) from customs control. Even though Saakashvili's government inherited from the previous government a rather unbalanced church-state relationship in the form of an agreement between the church and state dating back to 2002, it still could not follow the primary post-Rose Revolution inertia of secularization to fully tackle legal imbalances concerning other religious minorities and their rights. Hence after a few important reforms (e.g. Law on Education, and the arrest of radical Orthodox cleric Basil Mkalavrishvili who persecuted Jehovah's Witnesses), the government proved unable to propose a secular identity (Tevzadze 2010). As the next section of this paper will illustrate, the government's policies toward the GOC significantly differed from its secular/civic discourse.

\section{The making of Frankenstein: symphony in rosy colors}

Apart from legal aspects which strengthened the GOC's political positions, the Saakashvili government established the practice of preferential funding of the GOC. Research 
conducted by Transparency International (TI) estimated a sum of 200 million GEL (approximately $\$ 125$ million) allocated to the church's office during the last 12 years (TI 2013). The main sources of funding were twofold: private donations and state funding (see Figure 1). If in 2002 under President Shevardnadze, the Ministry of Finances allocated 857,600 GEL $(\$ 536,000)$ to the patriarchate in a year, after the Rose Revolution, in parallel with the growth of the state budget, there was a gradual increase in governmental funding of the church.

Figure 1 shows that in 2005 the state deposited 1,290,100 GEL (\$806,312); in 2006 and 2007, the funding was fourfold: 4,803,300 GEL (\$3 million) and 4,270,600 GEL (\$2.66 million), respectively. A dramatic increase in church funding is observed between 20072008 and 2008-2009. In 2008 Saakashvili's government funded the church with $12,933,400$ GEL ( $\$ 8.08$ million). This could be explained by the church's response to the political crisis of November 2007. The cause of the protests and political crisis was the decision by the government to amend the Constitution to extend parliament's term for another year in order to syncrhonize parliamentary and presidential elections. The opposition mobilized approximately 50,000 people against the legislative amendments which later turned into a political drama demanding Saakashvili's resignation. In response to the protests, the government used excessive force to disperse the crowds, cracked down on two independent oppositional TV stations (Imedi and Kavkasia) during live broadcasts, and imposed a state of emergency, prior to arresting an opposition leader (Chivers 2007; BBC 2007). This escalated into massive protests, leading Saakashvili to resign and hold snap presidential elections, which he narrowly won against opposition candidate Levan Gachechiladze. It is important to examine the position of the church during and after the crisis to understand church-state relations in the upcoming years. During the crisis in 2007, Patriarch Ilia II met opposition leaders, mediated between the two sides, and asked the protesters not to further escalate the crisis. Because of the authority of the patriarch, political tensions temporarily de-escalated, while after the snap elections, the patriarch attended Saakashvili's inauguration, thus giving symbolic legitimacy in the eyes of a religious population. The patriarch's political generosity was reflected in a drastic increase in church funding in 2008. The government employed clientelistic practices giving luxurious gifts to bishops; transferring real estate properties in various parts of Georgia to the possession of the GOC's patriarchate including hectares of agricultural land, farms, forests, and

\section{State budget funding allocated to the Georgian Patriarchate in 2002-2013 year (GEL million)}

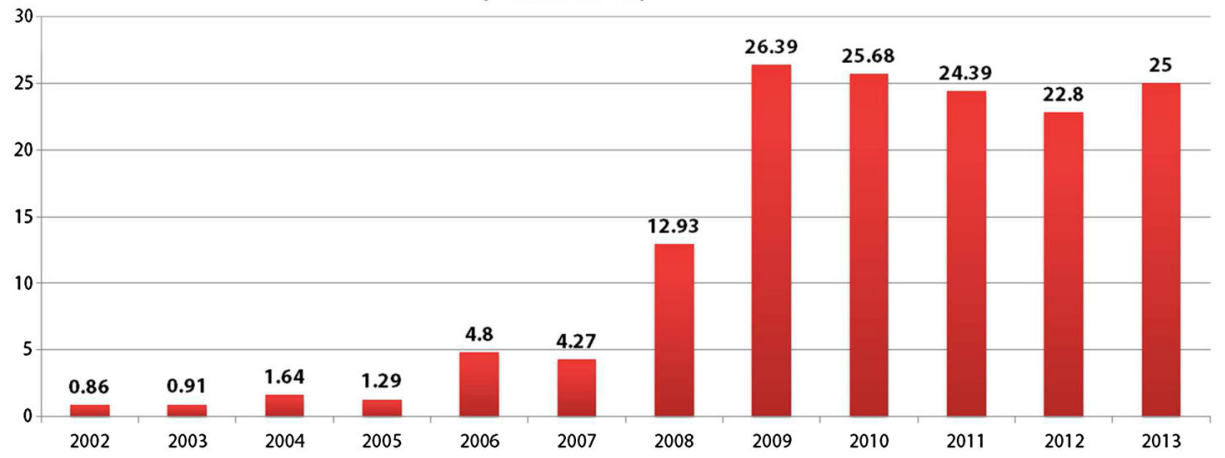

Figure 1. State budget funding allocated to the Georgian patriarchate in 2002-2013 (GEL million). 
recreational areas. In addition, the state issued direct annual funding estimated at $\$ 15$ million for the Orthodox Church (BBC 2007).

In 2009 , the state reached its highest level of revenue paid to the church amounting 26,394,900 GEL (\$16.5 million). Again, one might speculate about the growing dissatisfaction among the opposition due to the outcome of the Russo-Georgian war of August 2008, as well as the rise in popularity of antigovernment clerics and bishops. Little difference is noticed in the funding of the patriarchate in 2011 and 2012 - 24,391,700 ( $\$ 15.24$ million) in 2011 and 22,800,000 GEL (\$14.25 million) in 2012 (TI 2013). Apart from the Ministry of Finance, the state used presidential and governmental decrees to provide additional funding to the church. For example, the decrees authorized spending 8,388,200 GEL ( $\$ 5.24$ million) from the state budget on various activities between 2006 and 2012. In addition, from the Presidential Reserve Fund, 10,401,087 GEL (\$6.5 million) was transferred to the church, with a staggering 2,170,290 GEL (\$1.356 million) spent for purchasing luxury cars for church officials. A few days before the 2008 presidential election, the state allocated 1,700,000 GEL (\$1.06 million) to the church office from the presidential fund. In 2009, under government decree, state-funded evangelist TV station Ertsulovneba, also owned by the patriarchate of the GOC, was allocated 400,000 GEL $(\$ 250,000)$ from the government's reserve fund.

Another way of funding the church was through local municipalities and the transfer of real estate property to the Orthodox Church including hectares of farmland, plots for church buildings, forests, historical monuments, national parks, and protected areas (Grdzelidze 2009; TI 2013). On top of that, municipalities allocated around 16,000,000 GEL ( $\$ 10$ million) to the Georgian Patriarchate from 2002 to 2013 and assisted in financing various municipal events, restoration of churches and temples, and even the birthdays of bishops. Also, the practice of property transfer either for free or for a symbolic 1 GEL (60 cents) by the decree of the president, or by the decision of the Ministry of Economy and Sustainable Development and Tbilisi City Hall was very rampant. One example among many was a case where the GOC received a building with a total area of $4971.44 \mathrm{~m}^{2}$ with $2272 \mathrm{~m}^{2}$ of nonagricultural land for a symbolic 1 GEL (60 cents) through direct purchase in Tbilisi. Notable examples of land transfer to the church include $8200 \mathrm{~m}^{2}$ of nonagricultural land and $1310 \mathrm{~m}^{2}$ of buildings in Zestaponi municipality, Gardabani, Rustavi, the town of Aspindza, and Tbilisi, to name a few, and a rather exotic gift when the GOC received a cinema building located in Khulo municipality from the municipality with a total of $948.1 \mathrm{~m}^{2}$ of utility area and nonagricultural land (TI 2013).

If one compares the total combined 200,000,000 GEL ( $\$ 125$ million) that was allocated to the Georgian Patriarchate during the last 10 years to the funding available to other religious denominations under the UNM, Saakashvili's party, one sees a significant difference. For example, the government subsidized the Yezidi Union of Georgia, which received $1629 \mathrm{~m}^{2}$ of land in Varketili (Tbilisi) district for 1 GEL to build a Kurdish cultural center that would teach Kurdish and Georgian languages, history, culture, and computer courses. The Armenian Church received financial assistance amounting to 35,624 GEL in the period of 2009-2012. Until 2011 religious groups residing on Georgian territory Catholics, Muslims, or Jews - registered as organizations instead of religious communities. Saakashvili's government partially amended the state-led appeasement policy of the church in July by initiating modifications to the law to allow religious minority groups in Georgia to be registered "as legal entities of public law." A primary version of the draft law authorized the right to be registered as a legal entity of public law to those religions with "close historic ties with Georgia" (e.g. the Armenian Apostolic Church, the Roman Catholic Church, the Evangelical Baptist Church, Muslim communities, and Jewish 
communities). However, the final version of the law did not specify the aforementioned five religious groups, but allowed those religious groups to register as "religious."

An analysis of Saakashvili's religious policy showed strong favoritism toward the Orthodox Church. Whether it was driven by political calculations or not, the state established the practice of preferential treatment of the Orthodox Church (both by amending the legal framework in the church's favor and by authorizing direct funding and property donation practices). Even on a symbolic level, by changing an old national flag to a new Christian one without any discussion with the minority population, in addition to an exclusive attendance of Orthodox celebrations by state officials, and an inauguration on King David's grave, the state de facto codified Orthodox Christian culture as dominant at the expense of ignoring other religious traditions.

\section{The nation of nations in practice: the state's ethnicity policy}

In comparison with the state's religious policies, the government's policy toward ethnic minorities was relatively more inclusive, albeit incoherent. Actual measures for minority integration were more formal and short term rather than long term and sustainable. One of the reasons why the government's ethnicity policy differed significantly from religious policy could be linked to the requirements of the European Neighborhood Policy (ENP) that demanded certain criteria be met by signatory states, one of which was ensuring “ ... respect for rights of persons belonging to national minorities; sign and ratify European Charter for regional or Minority Languages" (EU-Georgia Action Plan 2004, 14). In fact that Association Agreement with the EU obliged governments to ensure religious equality:

Equal opportunities and anti-discrimination, aiming at enhancing gender equality and ensuring equal opportunities between men and women, as well as combating discrimination based on sex, racial or ethnic origin, religion or belief, disability, age or sexual orientation; meet equality similar criteria on religious affairs. (Chapter 14, Article 349 (e), Association Agreement 2014)

However, despite this clause and various reports by human rights organizations, the Saakashvili government tried to avoid adapting its religious policy to EU requirements until as late as 2011. In May 2011, by the end of the seventh year of Saakashvili's eight-year presidency, the state amended the civil code allowing other religious minority groups in Georgia to be registered as legal entities under public law. This was met by massive protests and public protests from the church (Serrano 2014). Given the crisis of November 2007, the Russo-Georgian war of 2008, and its aftermath, an inclusive ethnicity policy appeared politically more plausible and was favored over an equal and nondiscriminatory religious policy. This was reflected in structural changes in the state apparatus that institutionalized more involvement of the minority population in the political life of the country.

Several modifications in the state's structure resulted in the creation of institutions that were directly responsible for the issues of civil integration and ethnic minorities. At the executive level, the Office of the State Minister for Civic Integration Issues was among the first ministries assigned to deal with the issues of integration beginning in late 2004 . With a promising name and headed by an ethnic Ossetian, this ministry had a mandate for developing various sociocultural programs for minority integration. The appointment of an Ossetian in this position was part of the government's civic nationalism: it had more symbolic meaning and was aimed to illustrate the readiness of the government to incorporate ethnic minorities in high positions in the state structure. In this way perhaps Saakashvili's government sought to gain the trust of ethnic minorities and overcome their suspicion and disloyalty toward the state (Broers 2008). Putting the symbolical aspect aside, in practice this office did not lead to any serious achievements in any of the 
areas it was responsible for. It was more focused on the incorporation of Ossetian minorities (perhaps due to the ethnic background of the minister), but it could not succeed in this direction either. After several years of ineffective work, the office was abolished and was replaced by the State Minister's Office for Reintegration Issues, headed also by a representative of a minority community, this time Jewish. In addition, special advisors to the minister were appointed in the Javakheti and Kvemo Kartli regions (Sordia 2009). In this case, one needs to point out the failures of the bureaucratic apparatus of the state and to a certain extent mismanagement of minority integration into sociopolitical and economic life, rather than necessarily a failure of the civic concept of national identity advocated (at least discursively) by the government.

In 2006, Saakashvili's government established a special office of the Advisor to the President on Civic Integrations Issues. It was responsible for coordinating the work of the Tolerance and Civil Integration Council (established a year before) which was mandated to create the (first) strategic concept for the accommodation of ethnic pluralism. The Council itself consisted of key government officials, academics, and members of minority communities and minority-connected nongovernmental organizations. However, several factors delayed the adoption of the strategic concept for almost two years from the establishment of the Council. The two key factors were the gradual deterioration of Russian-Georgian relations and permanent reshufflings of Saakashvili's cabinet. The first led to the Russo-Georgian war in 2008, followed by the recognition of Abkhazian and South Ossetian independence by Russia (see Asmus 2010; Cornell and Starr 2009), while constant changes in the government resulted in incoherent policies toward minorities and a delay in the adoption of the state's strategy for their accommodation. However, incoherent policy does not mean nonexistence. Despite not having an official strategic concept until 2009, Saakashvili's government showed more effort toward minority incorporation than any of its predecessor governments. Due to the undefined territorial fragmentation of the state (rather than the lack of political will from the government's side), the main targets of the state's integrative policies were only those ethnic minorities who resided on territories under Georgian control, the Javakheti and Kvemo Kartli regions in particular.

The main problems the government had to address in these regions were the low levels of political participation, poor socioeconomic conditions (communicational isolation from the center, high levels of unemployment), and a lack of proficiency in the Georgian language (ICG 2011). These obstacles undermined the civic conception of the nation which Saakashvili's government attempted to construct. To deal with the problem of minority political participation, in 2005 the government established the School of Public Administration. The school focused on the academic recruitment of national minorities on matters of self-governance. It supported their participation by employing successful graduates in local government offices of the regions they represented (i.e. ethnic Armenian students were employed in Javakheti local administrative bodies, while ethnic Azerbaijanis in Kvemo Kartli units). In addition, the school ran several programs of Georgian as a second language for its students (Sordia 2009). Since its establishment, the school has produced 124 Armenian and 133 Azerbaijani graduates (ENP Report 2010).

To address socioeconomic issues and consequently to regain the loyalty of the minority population, with the help of assistance from Western donor organizations and institutions, the government gradually restored road connections with these regions; created local tourist infrastructure; settled electricity, gas, and water supply problems; invested in local hydropower plants; and supported the local agricultural sector (ICG 2011). These actions translated in changing attitudes within these communities, and showed positive trends in terms of enhancing loyalty toward state institutions. According to a survey carried out by the Civil 
Development Agency (CIDA), the perception of ethnic discrimination among minorities vanished with the provision of basic benefits by the government. The rehabilitation of infrastructure was named as "the most positive development over the last three years" by the majority of respondents. The key problem remained unemployment, but this nationwide problem was not interpreted as ethnic discrimination against minorities, as it was during Shevardnadze's presidency. In addition, almost 97\% (in Kvemo Kartli) and 69\% (in Javakheti) of respondents named Georgia as their homeland, whereas $81.7 \%$ of respondents named the presidency as the most trusted institution, followed by the army (79.5\%) and the police (79\%) (Report of CIDA 2011). Once national minorities saw taxpayers' money spent on their well-being, the suspicions, disloyalty toward the state, or threats of separatist movements were less of an issue. However, the nonexistence of similar surveys in previous years leaves one without enough information for a proper comparison. In addition, the loyalty of minorities toward the president or other state institutions could have been a result of the perception of external threats from Russia enhancing consolidation under the political idea of a nation and not necessarily linked with their satisfaction with the government's service.

Another important issue was the problem of general education in the Georgian language. The government brought highly qualified teachers in the social and natural sciences to non-Georgian schools and provided Georgian textbooks for free (Sordia 2009). However, soon after providing basic opportunities to study Georgian and acquire education in Georgian, the government amended the Law on General Education and as a result, the state enforced all public schools in the country (including those in minorityinhabited regions) to teach several social science subjects in Georgian by the 2010-2011 academic year (ICG 2011). According to the government's rationale, with the provision of resources for learning Georgian, the non-Georgian schools should have prepared "their pupils for life in a Georgian-speaking environment to a level comparable to that of Georgian schools" (Broers 2008, 296). In addition, the Law on Higher Education required minorities to take university entrance exams in the Georgian language. This put minority students in the same situation as the majority of their Georgian-speaking peers. Only three out of 64 ethnic minority students from Javakheti were admitted to state universities in the 2005-2006 and 2007-2008 academic years. The government also employed professional testing practices in the Georgian language for minority civil servants working in local governments, thus forcing them to study the state language. As a result, those who were not sufficiently competent in Georgian lost their jobs. Since the majority of the minority population in Javakheti and Kvemo Kartli did not speak Georgian, the government's policy could have been perceived as enforced assimilation (Wheatley 2006). It increased antagonism and strengthened the positions of local (minority) nationalists, rather than achieving its quasi-assimilationist goals.

Perhaps the threat of separatist mobilizations within these territories led the government to change this policy and start translating the national curricula into minority languages. After the failure of assimilationist policies, the Ministry of Education adopted the concept of Multilingual Education (MLE) for 2009-2011. This project was methodologically and technically supported by the Swiss organization CIMERA and funded by the Organization for Security and Cooperation in Europe's High Commissioner on Minorities (Sordia 2009). This program employed bilingual secondary education in some of the nonGeorgian public schools region-wide (around 40 pilot non-Georgian schools have already implemented this model). MLE provided minorities with the opportunity to study comparatively simple subjects in a bilingual environment (30\% of subjects in Georgian and $70 \%$ in their native language) (ICG 2011). It also aimed to reach half of the subjects being taught in 
Georgian within the next five years, however as an interdisciplinary international monitoring expert mission completed:

The quantitative and qualitative studies confirmed the hypothesis that piloting process is accompanied by the problems and difficulties (e.g. non-Georgian environment, low qualification of the teachers, lack of the methodological and teaching materials and etc.), which significantly hamper its implementation and questions its success if they are ignored. (Shubitidze 2011, 6)

In 2009, the government also (finally) amended the Law on Higher Education. As a result, it employed a new quota system for minorities. Instead of taking the entrance exams in Georgian (as was initially the case), national minorities took only one exam in their own language in order to enter university. This shift in policy reflected the dynamics of the minority admission process. Whereas in previous years only three minority students from Javakheti were successfully admitted to university, in 2010 this figure rose to 83 (out of 89 applicants) (Shubitidze 2011). The shifts in policy are reflected in CIDA's survey. Only a year and half after the implementation of MLE, 92\% of minorities responded "every citizen of Georgia should speak the state language." In addition, 82\% of the Kvemo Kartli and $65 \%$ of the Javakheti minority populations expressed their will to study Georgian. Although around 30\% still cannot speak the state language (Report on CIDA 2011), in 2006 this percentage was 83\% in Kvemo Kartli and 75\% in Javakheti (United Nations Association of Georgia 2006, 38).

Summing up Saakashvili's policy toward ethnic minorities, one might suggest that the implementation of MLE and amendments in the Law on Higher Education to a certain degree outline the aspirations of the state to integrate minorities into "societal culture," whereas the settlement of socioeconomic problems made this state-led nationalism more receptive to ethnic minorities. It also lessened their alienation from the majority population and strengthened loyalty toward state institutions. But in its initial phase, Saakashvili's nationalism needed more to create a homogenizing culture rather than the cultural assimilation of minorities, as it was at the beginning of his presidency. The shifts in civic direction emerged partially because of the growing antagonism among ethnic minorities and the government's suspicion of their separatist aspirations, the latter caused by the failure of the initial cultural assimilation policy of the state.

\section{Conclusion}

This paper has attempted to elaborate on the theoretical conceptualization of Georgian nationalism under the presidency of Mikheil Saakashvili. By examining interchangeable dichotomies between, on the one hand, political rhetoric and symbolism and, on the other, the legal framework and public policy, I suggest conceptualizing Georgian nationalism as hybrid nationalism. By focusing on different conceptions of nationhood as reflected in the state's religious and ethnicity policy, the paper identifies at times conflicting forms of national identity articulated by the ruling elites. Although the distinctions between the types of nationalism are blurry and vague, Saakashvili's nationalism to a degree was both a mixture of formerly experienced nationalism (ethnic) and a new hybrid type. Despite its various dichotomies, nationalism under the UNM moved in a more civic direction at the beginning of Sakashvili's presidency (the Law on General Education 2005 and the appointment of ethnic minorities to governing positions are examples). However, on a symbolic level and partly because of political calculations, it still carried certain elements of ethnic particularism toward the Orthodox Christian culture (e.g. selection of national flag, inauguration on the grave of David 
the Builder, and regular attendance of exclusively Orthodox Christian celebrations, until 2011, to name a few).

The evidence from Figure 1 suggests that soon after the political crisis of November 2007 when public dissatisfaction with Sakashvili's government reached its peak and led to massive protests and snap elections, state nationalism adopted practices of clientelism toward the GOC and ethnicity policy started to diverge from religious policy. The requirements set from the EU for signing the Association Agreement under the ENP were important external factors that could have influenced civic rhetoric and an inclusive ethnicity policy. Saakashvili's government employed institutional reforms and legislative amendments which echoed civic nationalism in policy. Certain important socioeconomic and educational reforms (e.g. implementation of the state's strategy of bilingual education) accelerated the integration of ethnic minorities, while the prevalent civic rhetoric made the diffusion of liberal values more effective compared to previous periods of Georgian history. However, the EU factor was not decisive in influencing the government's ethnocultural religious policy. Whether driven by political assertions of maintaining power or efforts to balance between the interests of different domestic and foreign actors, in an exchange for its loyalty, the government dramatically increased state funding of the church, donated state-owned land and property to it, gave various luxurious presents to bishops and high officials of the GOC, and made the church's commercial activity exclusively tax-exempt.

An inconsistency between different conceptions of nationhood as reflected in public policy and dichotomies in political rhetoric and the selection of symbols characterize what I hypothesize as hybrid nationalism. I argue that under hybrid nationalism, policies do not necessarily derive from a coherent national ideology - whether ethno-cultural or civic - but rather accommodate complex, and at times conflicting, political and social interests in discrepant public policies. Based on evidence presented in this paper, Georgian nationalism after the Rose Revolution constitutes such a case. It is doubtful that Georgian nationalism will decisively change to a liberal direction any time soon. As modernization of Georgian society and its system of values is still in progress, so is Georgian nationalism liberal and civic on paper, but with a reasonable amount of contradictions in practice.

\section{Notes}

1. Kymlicka defines the latter as "a territorially-concentrated culture, centred on shared language which is used in a wide range of societal institutions, in both public and private life - schools, media, law, economy, government etc. - covering the full range of human activities, including social, educational, religious, recreational, and economic life" $(2001,17)$.

2. As one of Saakashvili's close aides described to me in an informal setting, radical reforms were aimed at the "social engineering of Georgian mentality."

\section{References}

Anderson, Benedict. 1991. Imagined Communities: Reflections On the Origin and Spread of Nationalism. London: Verso.

Apple, Micheal. 1996. "Power, Meaning and Identity: Critical Sociology of Education in the United States." British Journal of Sociology of Education 17 (2): 125-144.

Asmus, Roland. 2010. A Little War that Shook the World: Georgia, Russia, and the Future of the West. New York: Palgrave Macmillan.

Association Agreement between the European Union and Georgia. 2014. http://eeas.europa.eu/ georgia/pdf/eu-ge_aa-dcfta_en.pdf.

BBC. 2007. "Tear Gas used on Georgia Protest." November 7. http://news.bbc.co.uk/2/hi/europe/ 7082317.stm. 
Broers, Laurence. 2008. "Filling the Void: Ethnic Politics and Nationalities Policy In Post-conflict Georgia." Nationalities Papers 36 (2): 275-304.

Brown, David. 2000. Contemporary Nationalism: Civic, Ethnocultural and Multicultural. London: Routledge.

Brubaker, Rogers. 1992. Citizenship and Nationhood in France and Germany. Cambridge, MA: Harvard University Press.

Chikvaidze, Davit. 2005. 'Sak'art'velos saxelmcip'osa da Sak'art'velos samoc'ik'ulo avtokep'alur mart'lmadidebel eklesias šoris Konstituc'iuri šet'anxmebis komenatariebi [Commentaries on the Constitutional Concordat between the Government of Georgia and Georgia's Apostolic Autocephalic Orthodox Church]." Tbilisi, Georgia.

Chivers, C. J. 2007. "Thousands Rally in Capital Against Georgia President." New York Times, November 3. http://www.nytimes.com/2007/11/03/world/europe/03tbilisi.html?_r=1\&oref= slogin.

Civil Georgia. 2008. "Donors Pledge USD 4.55 bln." October 22. http://www.civil.ge/eng/article. php?id=19810.

Companjen, Francoise. 2010. "Georgia." In The Colour Revolutions in the Former Soviet Republics: Successes and Failures, edited by Donnacha Ó Beacháin and Abel Polese, 13-29. London: Routledge.

Congressional Research Service. 2008. Armenia, Azerbaijan, and Georgia: Political Developments and Implications for US Interests. Washington, DC: Library of Congress.

Cornell, Svante, and Frederick Starr. 2009. The Guns of August 2008 Russia's War in Georgia. M.E. Sharpe: New York.

Deutsch, Karl. 1966. Nationalism and Social Communication. An Inquiry into the Foundations of Nationality. Cambridge, MA: MIT Press.

ENP (European Neighborhood Policy) Report. 2010. “Georgia's Progress Report on Implementation of the ENP Action Plan." Office of the State Minister of Georgia on European and EuroAtlantic Integration. http://eu-integration.gov.ge/uploads/ENPREPORT2010FINAL04_03_ 2011.doc.

EU-Georgia Action Plan. 2004. http://eeas.europa.eu/enp/pdf/pdf/action_plans/georgia_enp_ap_ final_en.pdf.

Eurasianet. 2004. "The Flag of Change: Georgia's New Banner.” March 25. http://www.eurasianet. org/departments/culture/articles/eav032604.shtml.

Fairbanks, Charles, Jr. 2004. “Georgia's Rose Revolution.” Journal of Democracy 15 (2): 110-124.

Filetti, Andrea. 2013. "Religion in South Caucasus: Encouraging or Inhibiting Pro-Democratic Attitudes?" Religion and Society in Central and Eastern Europe 6 (1): 33-45.

Furseth, Iinger, and Pål Repstad. 2006. An Introduction to the Sociology of Religion: Classical and Contemporary Perspectives. Aldershot: Ashgate.

Gale, Trevor. 2001. "Critical Policy Sociology: Historiography, Archaeology and Genealogy as Methods of Policy Analysis." Journal of Education Policy 16 (5): 379-393.

Gavashelshvil, Elene. 2012. "Anti-Modern and Anti-Globalist Tendencies in the Georgian Orthodox Church." Identity Studies 1 (4): 118-137.

Gellner, Ernest. 1964. Thought and Change. London: Weidenfeld and Nicolson.

Gellner, Ernest. 1983. Nations and Nationalism. Oxford: Blackwell.

Ghvinianidze, Lina, and Maia Barkaia. 2014. "Religion in public schools: An analysis of educational policy from the perspective of religious freedom." Human Rights Education and Monitoring Center (EMC), Tbilisi, Georgia.

Giragosian, Richard. 2004. "The US Military Engagement in Central Asia and the Southern Caucasus: An Overview." The Journal of Slavic Military Studies 17 (1): 43-77.

Glock, Charles, Benjamin Ringer, and Earl Babbie. 1967. To Comfort and to Challenge. Berkeley: University of California Press.

Glock, Charles, and Rodney Stark. 1965. Religion and Society in Tension. Chicago, IL: Rand McNally.

Grdzelidze, Tamara. 2009. "The Orthodox Church of Georgia: Challenges Under Democracy and Freedom (1990-2009)." International Journal for the Study of the Christian Church 10 (23): $160-175$.

Greenfeld, Liah. 1992. Nationalism: Five Roads to Modernity. Cambridge, MA: Harvard University Press.

Henry, Miriam. 1993. "What is Policy? A Response to Stephen Ball." Discourse, 14 (1): 102-105. 
International Crisis Group Report. 2011. "Georgia: The Javakheti Region's Integration Challenges." May 23. Europe Briefing $N^{\circ}$ 63. http://www.unhcr.org/refworld/docid/4ddba1712.html.

International Religious Freedom Report. 2005. "Bureau of Democracy, Human Rights and Labor." http://www.state.gov/j/drl/rls/irf/2005/51553.htm.

Jakopovich, Daniel. 2007. 'The 2003 'Rose Revolution' in Georgia: A Case Study in High Politics and Rank-and-file Execution." Debatte: Journal of Contemporary Central and Eastern Europe 15 (2): 211-220.

Jones, Stephen F. 2006. "The Rose Revolution: A Revolution without Revolutionaries?" Cambridge Review of International Affairs 19 (1): 33-48.

Jones, Stephen F. 2013. Georgia: A Political History Since Independence. London: I. B. Tauris \& Company.

Kekelia, Tatia. 2012. "Modernization and Secularization-Georgian Case Study." Identity Studies 1 (4): 90-106.

King, Charles. 2004. “A Rose among Thorns: Georgia Makes Good.” Foreign Affairs 83 (2): 13-18.

Kohn, Hans. 1944. The Idea of Nationalism. New York: Macmillan.

Kymlicka, Will. 1995. Multicultural Citizenship: A Liberal Theory of Minority Rights. Oxford: Oxford University Press.

Kymlicka, Will, and Magda Opalski. 2001. Can Liberal Pluralism be Exported? Western Political Theory and Ethnic Relations in Eastern Europe. Oxford: Oxford University Press.

Ladaria, Konstantin. 2012. "Georgian Orthodox Church and Political Project of Modernization." Identity Studies 1 (4): 107-117.

Law on General Education [kanoni zogadi ganatlebis shesakheb]. 2005. http://www.mes.gov.ge/ uploads/Licenzireba/kanoni\%20zogadi\%20ganatlebis\%20shesaxeb.pdf.

Lazarus, Joel. 2010. "Neo-liberal State Building and Western 'Democracy Promotion': The Case of Georgia." In SGIR 7th Pan-European Conference, Stockholm, Sweden.

Marshall, Catherine. 1997. "Dismantling and Reconstructing Policy Analysis." In Feminist Critical Policy Analysis I: A Perspective from Primary and Secondary Schooling, edited by C. Marshall, 1-39. London: Falmer Press.

Mitchell, Lincoln. 2004. "Georgia's Rose Revolution.” Current History 103 (675): 342-348.

Nodia, Ghia. 2009. "Components of the Georgian National Identity: An Outline." Identity Studies 1 (1): 84-101.

Ozga, Jenny. 1987. "Studying Educational Policy through the Lives of Policy Makers: An Attempt to Close the Macromicro Gap." In Changing Policies, Changing Teachers, edited by Stephen Walker and Len Barton, 138-150. Milton Keynes: Open University Press.

Payne, Daniel P. 2007. "Nationalism and the Local Church: The Source of Ecclesiastical Conflict in the Orthodox Commonwealth." Nationalities Papers 35 (5): 831-852.

Prunty, John. 1985. "Signposts for a Critical Educational Policy Analysis." Australian Journal of Education 29 (2): 133-140.

Ramet, Sabrina P. 2006. "The Way We Were - and Should be Again? European Orthodox Churches and the 'Idyllic Past'." In Religion in an Expanding Europe, edited by Timothy A. Byrnes and Peter Katzenstein, 148-175. New York: Cambridge University Press.

Ratiani, Sergo. 2011. "Differing Political Theologies of Differing Eras." Identity Studies 1 (3): $51-75$.

Report of Civil Development Agency (CIDA). 2011. "To the UN Committee on the Elimination of Racial Discrimination for the 79th Session.” August 8-September 2. http://www2.ohchr.org/ english/bodies/cerd/docs/ngos/CiDA_Georgia79.pdf.

Rice, Tom W. 2003. "Believe it or Not: Religious and Other Paranormal Beliefs in the United States." Journal for the Scientific Study of Religion 42 (1): 95-106.

Roof, Wade C. 1976. "Traditional Religion in Contemporary Society: A Theory of LocalCosmopolitan Plausibility." American Sociological Review 41 (2): 195-208.

Saakashvili, Mikheil. 2004. Mikheil Saakashvili Sworn In. http://www.president.gov.ge/index.php? lang_id=ENG\&sec_id=219\&info_id=4990.

Saakashvili, Mikheil. 2005. President Saakashvili Meets with Law-Enforcements at the Constitutional Security Department. http://www.president.gov.ge/index.php?lang_id=ENG\&sec_id=228\&info_ $\mathrm{id}=4835$.

Saakashvili, Mikheil. 2008a. The President of Georgia Mikheil Saakashvili's Address to the Population of Georgia. http://www.president.gov.ge/index.php?lang_id=ENG\&sec_id=228\&info_id=4188. 
Saakashvili, Mikheil. 2008b. The President of Georgia Addressed Abkhazian and Ossetian Population with Peace Initiative. http://www.president.gov.ge/index.php?lang_id=ENG\&sec_id=228\&info_ id $=4210$.

Saakashvili, Mikheil. 2008c. The President of Georgia Met Refugees and the Veterans of the War of the 90ies. http://www.president.gov.ge/index.php?lang_id=ENG\&sec_id=228\&info_id=4222.

Sak'art'velos sagadasakhado kodeqsi [Georgian Tax Code]. 2010. http://www.forms.ge/kodex.

Serrano, Silvia. 2010. "De-Secularizing National Space in Georgia." Identity Studies 1 (2): 37-58.

Serrano, Silvia. 2014. "The Georgian Church Embodiment of National Unity or Opposition Force?" Russian Politics and Law, 52 (4): 74-92.

Shubitidze, Irine. 2011. "Language Policy and Difficulties in the State Language Teaching Process in Georgia." Centre for Civil Integration and Inter-Ethnic Relations: Tbilisi, Georgia.

Smith, Anthony D. 1991. National Identity. Harmondsworth: Penguin.

Smith, Anthony D. 2009. Ethno-Symbolism and Nationalism. London: Routledge.

Sordia, Giorgi. 2009. "Institutions of Georgia for Governance on National Minorities: An Overview." European Centre for Minority Issues, Working paper \# 43. http://www.ecmi.de/publications/ detail/43-institutions-of-georgia-for-governance-on-national-minorities-an-overview-153/.

Stark, Rodney, and William S. Bainbridge. 1980. "Towards a Theory of Religion: Religious Commitment." Journal for the Scientific Study of Religion 19 (2): 114-128.

Sulkhanishvili, Irina. 2012. "Struggle for Power: Religion and Politics in Georgia from the 90s to the Present." Identity Studies 1 (4): 138-152.

Taylor, Sandra. 1997. "Critical Policy Analysis: Exploring Contexts, Texts and Consequences." Discourse 18 (1): 23-35.

Tevzadze Gigi. 2009. "The Birth of the Georgian Nation. Identity and Ideology. Political and Societal Identities. Nationality and Religiosity." Identity Studies 1 (1): 5-21.

Tevzadze, Gigi. 2010. "Secularization and the Birth of a Nation." Identity Studies 1 (1): 59-78.

Tomka, Miklós. 2011. Expanding Religion. Religious Revival in Post-Communist Central and Eastern Europe. New York: Walter de Gruyter.

Transparency International. 2013. "An Overview of Public Financing Provided to the Georgian Patriarchate." http://transparency.ge/en/blog/overview-public-financing-provided-georgianpatriarchate.

Tudoroiu, Theodor. 2007. "Rose, Orange, and Tulip: The Failed Post-Soviet Revolutions." Communist and Post-Communist Studies 40 (3): 315-342.

United Nations Association of Georgia. 2006. National Integration and Tolerance in Georgia: Assessment Survey Report. United Nations Association of Georgia, http://www.diversity.ge/ files/files/ASR/NITG_Assesment_survey_report_Report.pdf.

Wheatley, Jonathan. 2005. Georgia from National Awakening to Rose Revolution Delayed Transition in the Former Soviet Union. Aldershot: Ashgate.

Wheatley, Jonathan. 2006. "The Status of Minority Languages in Georgia and the Relevance of Models from Other European States." European Centre for Minority Issues, Working paper \# 26. http://www.ecmi.de/publications/detail/26-the-status-of-minority-languages-in-georgiaand-the-relevance-of-models-from-other-european-states-170/.

Wheatley, Jonathan. 2009. "Georgia and the European Charter for Regional or Minority Languages." European Centre for Minority Issues, Working paper \# 42. http://www.ecmi.de/publications/ detail/42-georgia-and-the-european-charter-for-regional-or-minority-languages-154/.

Yack, Bernard. 1999. "The Myth of Civic Nation." In Theorizing Nationalism, edited by Ronald Beiner, 103-118. Albany, NY: SUNY Press.

Zedania, Giga. 2009. "National Form and the Question of Identity." Identity Studies 1 (1): 75-83.

Zuckerman, Phil. 2008. Society Without God. New York: New York University Press. 